\title{
Kajian tentang Penerapan Sanksi Pidana terhadap Pelaku yang Melakukan Perbuatan Curang dalam Bisnis Dihubungkan dengan Pasal 379a Kitab Undang-Undang Hukum Pidana
}

\author{
M Rendi Aridhayandi \\ Faculty of Law, Suryakancana University, Cianjur, Indonesia \\ jmj.fh.unsur@gmail.com
}

Submitted: 2017-03-03; Reviewed: 2017-05-05; Accepted: 2017-06-06

\begin{abstract}
Business is one of main activity in supporting national economic matter. Business activity run by businessman, varied according to their existence in regulation, activity or legal standing. In lower level for example, businessman are person with limited resources, but for middle or higher level, the activity run by business entity including incorporated and not a legal entity such person or cooperative as a corporation. This article examine legal aspect in applying criminal sanction to businessmen who act fraud in business according to Article 379a Criminal Code of Indonesia (KUHP). This article also examine the reason for those fraud action and analyze the enforcement by law enforcer. The result show that business is one of economic activity that seek profit but in some way the activity run by using inappropriate action which hurm other businessman. The reason for those fraud action are the weaknes of human resources; unethical behavior in business activity; and the weakness of law enforcement. Enforcement of article 379a in order to ensure legal certainty, equality before the law and legal protection still work slowly.
\end{abstract}

Keywords: Article 379a of Criminal Code of Indonesia; Business; Fraud Action

\section{PENDAHULUAN}

Manusia sebagai makhluk sosial tentu tidak mungkin dapat memisahkan hidupnya dengan manusia lain. Sudah bukan rahasia lagi bahwa segala bentuk kebudayaan, tatanan hidup, dan sistem kemasyarakatan terbentuk karena interaksi dan benturan kepentingan antara satu manusia dengan manusia lainnya. ${ }^{1}$

Pergaulan dalam hidup menurut Bimo Adi Wicaksono, bertujuan untuk mempertahankan diri, mendapat kehidupan yang aman, damai, tertib termasuk dalam memenuhi kebutuhan

\footnotetext{
${ }^{1}$ Abdi Anwar Rasyid, Ilmu Sosial Dasar; Manusia Sebagai Makhluk Sosial, Bandung: Bina Cipta, 2013, hlm. 17.
} 
hidupnya. $^{2}$ Kemajuan teknologi yang semakin hari semakin canggih di segala sektor kehidupan dalam masyarakat. Memudahkan masyarakat untuk melakukan segala sesuatu yang dikehendakinya, serta membawa kehidupan masyarakat ke arah perubahan yang begitu pesat yang semula bercorak kehidupan tradisional menuju masyarakat yang lebih modern atau yang istilahnya dikenal sekarang ini sebagai modernisasi. ${ }^{3}$ Bahkan melalui kemajuan ilmu pengetahuan dan teknologi yang pesat, proses interaksi tersebut bukan hanya antar individu, antar kelompok, tetapi sudah melintasi batas-batas negara yang dikenal dengan istilah globalisasi.

Globalisasi mengandung implikasi makna yang dalam di segala aspek kehidupan, salah satunya dibidang bisnis atau dagang. Bisnis merupakan salah satu aktivitas usaha yang utama dalam menunjang perekonomian nasional. Hal ini dapat dilihat dari beberapa pandangan yang disampaikan para pihak yang memiliki perhatian pada bidang ekonomi. Bisnis menurut Haney adalah aktivitas manusia yang dihubungkan dengan produksi ataupun memperoleh kekayaan melalui pembelian dan penjualan barang. Lebih lanjut Peterson dan Plowman menjelaskan bahwa bisnis merupakan serangkaian kegiatan yang berhubungan dengan penjualan ataupun pembelian barang dan jasa yang secara konsisten berulang. ${ }^{4}$

${ }^{2}$ Bimo Adi Wicaksono, "Pengaruh Iptek Dalam Kehidupan Sehari-hari", diakses tanggal 9 Desember 2014.

3 A.K. Mihardja, Polemik Kebudayaan, Jakarta: Balai Pustaka, 1998, hlm. 19.

${ }^{4}$ Indah Kusumawardani, Pengertian Bisnis Secara Umum Menurut Ahli, artikel dalam http: //www.apapengertianahli.com/2014/09/pengertian-
Para pelaku ekonomi tersebut dari strata manapun berasal, menurut L.R.Dicksee dalam menjalankan kegiatan bisnis tujuan utamanya untuk memperoleh keuntungan yang sebesarnya dengan pengorbanan yang sekecil-kecilnya. ${ }^{5}$ Bahkan untuk mendapatkan keuntungan tersebut, para pelaku bisnis terkadang melakukan bisnis curang dengan melanggar etika bisnis, karena para pelaku bisnis tersebut berpandangan bahwa bisnis merupakan kegiatan usaha yang di dalamnya penuh persaingan, dan semua perilaku dari pihak-pihak yang bersaing tersebut ingin keluar sebagai pemenangnya. Oleh karena itu, kegiatan bisnis dilakukan dengan tidak memperhatikan moral atau etika, ${ }^{6}$ bahkan untuk mendapatkan keuntungan yang sebesar-besarnya tersebut, terkadang dilakukan dengan merugikan pihak lain.

Sebagai contoh, kasus yang terjadi pada perusahaan $\mathrm{X}$ yang bergerak di bidang agribisnis peternakan ayam, khususnya penyediaan sarana produksi ternak (pakan ayam, anak ayam, obatobatan). Perusahaan tersebut membangun kemitraan dengan pihak perusahaan $\mathrm{Y}$ untuk menyuplai sarana produksi ternak (pakan ayam, anak ayam, obat-obatan). Setelah perusahaan $\mathrm{X}$ beberapa kali menyuplai pakan ayam tersebut, pihak perusahaan $\mathrm{Y}$ tidak secara penuh melakukan pembayaran hutang atas sarana produksi ternak (pakan ayam, anak ayam, obat-obatan) tersebut dan hal tersebut dilakukan secara berulang-ulang. Bahkan perbuatan tersebut, bukan hanya dilakukan

bisnis-menurut-para-ahli.html, diakses tanggal 23 Februari 2015.

${ }^{5}$ Ibid,.

${ }^{6}$ Es. Mahmoedin, Etika Bisnis Perbankan, Jakarta: Pustaka Sinar Harapan, 1994, hlm. 72-76. 
pada perusahaan $X$ saja, tetapi juga perusahaan-perusahaan lainnya.

Hubungan kemitraan antara perusahaan $\mathrm{X}$ dan perusahaan $\mathrm{Y}$, dan tidak dipenuhinya pembayaran tersebut merupakan konsep hukum privat yang dikenal dengan istilah wanprestasi. Namun penyelesaian persoalan tersebut tidak selalu berhubungan dengan penyelesaian hukum privat, tetapi melalui instrumen hukum pidana, sebagaimana diatur dalam Pasal 379a KUHP. Perusahaan Y melakukan tindakan penipuan yang sudah dijadikan mata pencaharian atau kebiasaan dengan modus operandi mengambil barang dengan membayar setengah dari kewajiban yang harus dibayar, sementara sisanya tidak dilunasi.

Oleh karena itu, hukum pidana diberikan peranan luas dalam menertibkan pelaksanaan bisnis sekarang ini yang sedang menghadapi era globalisasi atau perubahan, dimana tentunya akan memunculkan masalah-masalah baru dalam dunia bisnis. Keterlibatan hukum pidana dalam dunia bisnis ditujukan untuk memberikan perlindungan/jaminan rasa aman dan keamanan bagi pelaku usaha dalam menjalankan bisnisnya.

Selain itu, penggunaan hukum pidana dimaksudkan agar dapat memenuhi rasa keadilan dan untuk melindungi masyarakat dari setiap kejahatan atau tindak pidana, hal ini disebabkan karena Indonesia adalah negara hukum berdasarkan Pasal 1 ayat (3) Undang-Undang Dasar Negara Republik Indonesia Tahun 1945. Oleh sebab itu penulis merumuskan masalah sebagai berikut: (1) Bagaimanakah aspek-aspek hukum dalam penerapan sanksi pidana terhadap pelaku usaha yang melakukan perbuatan curang dalam bisnis perspektif Pasal 379a KUHP, (2) Faktor penyebab terjadinya perbuatan curang dalam bisnis yang dilakukan oleh pelaku usaha, (3) Upaya apakah yang dilakukan oleh aparat penegak hukum dalam penerapan sanksi pidana terhadap pelaku yang melakukan perbuatan curang dalam bisnis dalam kerangka penegakan hukum pidana.

\section{PEMBAHASAN}

\section{Tindak Pidana dan Bisnis.}

Pembentuk Undang-Undang dalam berbagai perundang-undangan menggunakan perkataan "tindak pidana" sebagai terjemahan dari "strafbaar feit" tanpa memberikan sesuatu penjelasan mengenai apa yang sebenarnya dimaksud dengan perkataan "tindak pidana" tersebut. Secara harfiah perkataan "tindak pidana" dapat diterjemahkan sebagai "sebagian dari suatu kenyataan yang dapat dihukum". Akan tetapi, diketahui bahwa yang dapat dihukum sebenarnya adalah manusia sebagai pribadi dan bukan kenyataan, perbuatan, ataupun tindakan. ${ }^{7}$

Tindak pidana juga dapat diartikan sebagai suatu dasar yang pokok dalam menjatuhi pidana pada orang yang telah melakukan perbuatan pidana atas dasar pertanggungjawaban seseorang atas perbuatan yang telah dilakukannya. Akan tetapi, sebelum itu mengenai dilarang dan diancamnya suatu perbuatan mengenai perbuatannya sendiri berdasarkan asas legalitas (Principle of Legality) yang menentukan bahwa tidak ada perbuatan yang dilarang dan diancam dengan pidana jika tidak ditentukan terlebih dahulu dalam

\footnotetext{
${ }^{7}$ P.A.F. Lamintang, Dasar-Dasar Hukum Pidana Indonesia, Bandung: Citra Aditya Bakti, Bandung, 1997, hlm. 181.
} 
perundang-undangan (Nullum Delictum Nulla Poena Sine Praevia Lege Poenali).

Selanjutnya mengenai bisnis, ada beberapa para ahli yang mengemukakan pendapatnya tentang bisnis, berikut ini akan dijelaskan dengan jelas:

Owen menjelaskan bahwa bisnis ialah suatu perusahaan yang berkaitan dengan produksi dan distribusi barang untuk dijual kembali ke pasar atau memberikan harga dalam setiap barang ataupun jasa. Kemudian, Urwick dan Hunt, menyatakan bisnis ialah setiap perusahan yang memproduksi dan mendistribusikan serta menyediakan barang atau jasa yang diperlukan masyarakat dan atas dasar kesediaannya dalam membeli atau membayar dan terakhir, Mc. Naughton juga menegaskan bisnis sebagai suatu pertukaran barang, jasa ataupun uang dengan tujuan memperoleh keuntungan.

Membicarakan tentang kejahatan bisnis tentunya tidak terlepas kaitannya dengan suatu tindak pidana, yaitu suatu tindak pidana yang dikategorikan sebagai tindak pidana khusus di bidang bisnis. Tindak pidana tersebut meliputi antara lain: pelanggaran undang-undang anti monopoli, penipuan melalui komputer, pembayaran pajak dan cukai, pelanggaran harga, produksi yang membahayakan kesehatan, pelanggaran administratif, pencemaran lingkungan hidup, korupsi (penyuapan), perburuhan dan sebagainya, ${ }^{8}$ atau secara operasional mencakup:

a. Tindak pidana yang melanggar peraturan hukum yang mencoba mengatur agar kompetisi dilakukan secara jujur dan efektif dan

8 Muladi, Fungsionalisasi Hukum Pidana Di Dalam Kejahatan Yang Dilakukan Oleh Korporasi, Makalah, Fakultas Hukum UNDIP Semarang, 1989, hlm 2. mencegah penyalahgunaan.

Termasuk penipuan (fraud) yang

dilakukan dalam perdagangan, peraturan anti trust, perlindungan konsumen, perlindungan buruh dan perlindungan terhadap lingkungan hidup;

b. Tindak pidana yang melanggar peraturan hukum yang mengatur ekonomi pasar. Termasuk pengendalian harga, peraturan impor-ekspor dan peraturan devisa.

c. Tindak pidana fiskal dan bea cukai;

d. Korupsi, khususnya suap-menyuap. ${ }^{9}$

Kemudian, ada berbagai bentuk usaha yang digunakan dalam menjalankan kegiatan bisnis, yaitu sebagai berikut:

a. Perusahaan perseorangan.

b. Firma (Fa).

c. Perseorangan Komonditer (CV);

d. Perseroan Terbatas (PT).

e. Perusahaan Negara.

1. Perusahaan Jawatan (Perjan).

2. Perusahaan umum (Perum).

3. Perusahaan Persero.

f. Perusahaan Daerah;

g. Yayasan;

h. Koperasi.

Selanjutnya Hoeber memberikan beberapa bentuk dari tindak pidana bisnis, antara lain:

a. Membuka usaha secara melawan hukum, misalnya membuka perusahaan semata-mata untuk tujuan mematikan usahawan lain yang menjadi musuhnya;

9 Herman Susetyo, Pelaku Kejahatan Bisnis, Dampak dan Tanggungjawabnya, Makalah disampaikan Pada Bagian Keperdataan Pada Tanggal 9 Januari 1995, Fakultas Hukum Universitas Diponegoro, 1995, hlm. 3. 
b. Mencegah atau mengganggu terjadinya kontrak;

c. Penghinaan atau pencemaran nama baik seseorang atau perusahaan lain (defamation) atau pencemaran mutu barang perusahaan lain (slander of quality atau trade libel);

d. Praktik-praktik perdagangan yang curang/tidak jujur (unfair trade practices) antara lain:

1. Pemasaran curang (fraudulent marketing);

2. Pelanggaran merek dan nama dagang (infringing trade mark or trade name);

3. Pelanggaran paten atau hak cipta (infringing patent or copyright);

4. Pelanggaran rahasia perdagangan (violating trade secrets).

\section{Perbuatan Curang Dalam Bisnis.}

Mengenai dampak perbuatan curang dalam bisnis dimana secara dalam hukum dapat dipisahkan menjadi dua klasifikasi, yakni kerugian materil dan kerugian imateril:

a. Kerugian Materil, yaitu kerugian yang nyata-nyata ada yang diderita;

b. Kerugian Immateril, yaitu kerugian atas manfaat yang kemungkinan akan diterima di kemudian hari atau kerugian dari kehilangan keuntungan yang mungkin diterima di kemudian hari. ${ }^{10}$

\footnotetext{
${ }^{10}$ Diakses melalui http: // www.hukumonline.com / klinik / detail / lt4da27259c45b9 / di-manapengaturan-kerugian-konsekuensial-dalam-hukumindonesia, pada tanggal 5 Agustus 2015, pada Pukul 09.20 WIB.
}

Kecurangan atau curang identik dengan ketidakjujuran atau tidak jujur, dan sama pula dengan licik, meskipun tidak serupa benar. Curang atau kecurangan artinya apa yang diinginkan tidak sesuai dengan hari nuraninya atau orang itu memang dari hatinya sudah berniat curang dengan maksud memperoleh keuntungan tanpa bertenaga dan berusaha. Kecurangan menyebabkan orang menjadi serakah, tamak, ingin menimbun kekayaan yang berlebihan dengan tujuan agar dianggap sebagai orang yang paling hebat, paling kaya, dan senang bila masyarakat disekelilingnya hidup menderita.

Bermacam-macam sebab orang melakukan kecurangan. Ditinjau dari hubungan manusia dengan alam sekitarnya, ada 4 (empat) aspek yaitu aspek ekonomi, aspek kebudayaan, aspek peradaban dan aspek teknik. Apabila keempat aspek tersebut dilaksanakan secara wajar, maka segalanya akan berjalan sesuai dengan norma-norma moral atau norma hukum. Akan tetapi, apabila manusia dalam hatinya telah digerogoti jiwa tamak, iri, dengki, maka manusia akan melakukan perbuatan yang melanggar norma tersebut dan jadilah kecurangan. ${ }^{11}$

Kecurangan merupakan penipuan yang dibuat untuk mendapatkan keuntungan pribadi atau untuk merugikan orang lain. Dalam hukum pidana, kecurangan adalah kejahatan atau pelanggaran yang dengan sengaja menipu orang lain dengan maksud untuk merugikannya, biasanya untuk memiliki sesuatu/harta benda atau jasa

$11 \quad$ Diakses melalui http://fthund.blogspot.com/2012/06/pengertiankecurangan-kecurangan-atau.html, pada tanggal 6 Agustus 2015, Pada Pukul 11.00 WIB. 
ataupun keuntungan dengan cara tidak adil/curang. Kecurangan dapat mahir melalui pemalsuan terhadap barang atau benda. Dalam hukum pidana secara umum disebut dengan "pencurian dengan penipuan", "pencurian dengan tipu daya/muslihat", "pencurian dengan penggelapan dan penipuan" atau hal serupa lainnya. ${ }^{12}$

Bentuk-bentuk penipuan tersebut adalah sebagai berikut:

1. Penipuan Pokok.

2. Penipuan Ringan.

3. Penipuan dalam Jual Beli.

4. Penipuan yang dilakukan oleh penjual kedua.

Selanjutnya tindak pidana penipuan memiliki unsur-unsur pokok, yaitu:

1. Dengan maksud untuk menguntungkan diri sendiri atau orang lain secara melawan hukum.

2. Dengan menggunakan salah satu atau lebih alat penggerak penipuan (nama palsu, martabat palsu atau keadaan palsu, tipu muslihat dan rangkaian kebohongan).

Sifat dari penipuan sebagai tindak pidana ditentukan oleh cara-cara pelaku menggerakkan orang lain untuk menyerahkan barang. Alat-alat penggerak yang digunakan untuk menggerakkan orang lain adalah sebagai berikut:

1. Nama Palsu.

2. Tipu Muslihat.

3. Martabat atau Keadaan Palsu.

4. Rangkaian Kebohongan.

5. Menggerakkan orang lain untuk menyerahkan sesuatu barang, atau

$12 \quad$ Diakses melalui http://sarahabibah.blogspot.com/2012/06/kecurang an-dan-sebab-orang-melakukan.html, pada tanggal 6 Agustus 2015, Pada Pukul 11.00 WIB. memberi utang, atau menghapus hutang.

\section{Perbuatan Curang dalam Peraturan.}

Dalam KUHP perbuatan curang diatur pada bab XXV Pasal 378 sampai dengan Pasal 395, yang sanksi pidananya Pasal 379a diuraikan sebagai berikut:

Pasal 379a:

"Barang siapa menjadikan sebagai mata pencaharian atau kebiasaan untuk membeli barang-barang, dengan maksud supaya tanpa pembayaran seluruhnya memastikan penguasaan terhadap barang-barang itu untuk diri sendiri maupun orang lain, diancam dengan pidana penjara paling lama empat tahun:

Hukuman adalah tindakan yang ditujukan kepada pribadi atau badan hukum yang melakukan pelanggaran pidana. Hukuman atau sanksi yang dianut oleh hukum pidana yang ditujukan untuk memelihara keamanan dan pergaulan hidup teratur, menjadi perdebatan para pakar dalam dasar diadakannya hukuman tersebut yang akhirnya menimbulkan tiga teori yaitu:
a. Teori Imbalan (absolute / vergeldingstheorie);
b. Teori Maksud atau Tujuan (relatieve / doeltheorie);
c. Teori (vereningingstheorie). ${ }^{13}$
Gabungan
Teori Imbalan (absolute / vergeldingstheorie).

13 Leden Marpaung, Asas, Teori dan Praktik Hukum Pidana, Bandung: Sinar Grafika, 2006, hlm. 105. 
Menurut teori ini dasar hukum harus dicari dari kejahatan itu sendiri karena kejahatan itu telah menimbulkan penderitaan bagi orang lain. Sebagai imbalannya (vergeliding) pelaku juga harus diberi penderitaan. Para pakar penganut ini adalah Imanuel Kant, Hegel, Jean Jecques Rousseau, dan Stahl.

Teori Maksud atau Tujuan (reloatieve/doeltheorie). Berdasarkan teori ini hukuman dijatuhkan berdasarkan maksud dan tujuan dari hukuman ini yakni memperbaiki ketidakpuasan masyarakat sebagai akibat dari kejahatan itu. Tujuan hukuman harus dipandang secara ideal. Selain itu, tujuan hukuman adalah untuk mencegah (prevensi) kejahatan namun terdapat perbedaan dalam hal prevensi, yakni: pertama ada yang berpendapat agar prevensi ditujukan kepada umum yang disebut prevensi umum (algemene preventie) hal ini dapat dilakukan dengan ancaman hukuman penjatuhan hukuman dan pelaksanaan (eksekusi) hukuman, kedua ada yang berpendapat agar prevensi ditujukan kepada orang yang melakukan kejahatan itu (speciale preventie).

Teori Gabungan (verenigingstheorie), pada dasarnya teori ini merupakan gabungan dari teori imbalan dan teori tujuan. Mengajarkan bahwa hukuman untuk mempertaruhkan tata tertib hukum dalam masyarakat dan memperbaiki pribadi si penjahat, dengan menelaah teori-teori di atas dapat disimpulkan bahwa tujuan pemidanaan adalah: a) Menjerakan Penjahat; b) Membinasakan atau membuat tak berdaya lagi si penjahat; c) Memperbaiki penjahat. ${ }^{14}$

\footnotetext{
${ }^{14}$ Ibid., hlm. 107.
}

Pada hakikatnya ketiga hal tersebut menjadi dasar diadakannya sanksi Pidana, akan tetapi membinasakan penjahat masih menjadi masalah perdebatan para pakar. Sebagian negara memang telah menghapuskan hukuman mati, tetapi sebagian lagi masih dapat menerimanya.

Hukuman atau tindak pidana terdiri dari berbagai jenis bentuknya. Akan tetapi, sesuai dengan Bab II Pasal 10 KUHP adalah terdiri dari:

1. Pidana Pokok.

a. Pidana Mati;

b. Pidana Penjara;

c. Pidana Kurungan; dan

d. Pidana Denda.

2. Pidana Tambahan.

a. Pencabutan hak-hak tertentu;

b. Perampasan barang-barang tertentu;

c. Pengumuman putusan hakim.

\section{Bisnis dan Faktor-Faktor / Motif Perbuatan Curang.}

Keberhasilan suatu bisnis sebagian besar diukur juga berdasarkan nilai dan norma yang berlaku dalam masyarakat itu, termasuk nilai dan norma yang berlaku dalam masyarakat itu, tidak hanya ditentukan oleh kiat bisnis murni, melainkan juga penghayatan terhadap nilai dan norma sosial.

Dalam bisnis memang ada persaingan yang ketat, tetapi tidaklah benar pandangan bahwa pengusaha yang mematuhi aturan moral akan berada dalam posisi yang tidak menguntungkan bahkan tersingkir. Dasi sudut pandang pebisnis sendiri semakin disadari bahwa bisnis yang berhasil adalah bisnis yang memperhatikan norma-norma moral. Pengusaha sadar bahwa bisnisnya akan 
hancur kalau konsumen (langganan), tidak mempercayai lagi produk yang dihasilkan dari bisnisnya, demikian juga jika mitra bisnisnya dirugikan melalui perbuatan curang sebagaimana diatur dalam Pasal 379a KUHP.

Ada beberapa faktor yang menyebabkan palaku bisnis melakukan perbuatan curang yang dapat dibagi ke dalam dua sisi, yaitu dari sisi intern pelaku usaha itu sendiri, dan dari sisi ekstern. Secara intern, faktor penyebab atau alasan pelaku usaha melakukan perbuatan curang, diantaranya yaitu:

1. Lemahnya Sumber Daya Manusia (SDM).

2. Sikap atau rasionalisasi untuk membenarkan tindakan fraud. ${ }^{15}$

3. Kurangnya kesadaran moral utilitarian (moral yang berkaitan dengan memaksimumkan hal terbaik bagi orang sebanyak mungkin).

4. Menurunnya formalism etis (moral yang berfokus pada maksud yang berkaitan dengan perilaku dan hak tertentu.

5. Pandangan yang salah dalam menjalankan bisnis, dimana tujuan utama bisnis adalah mencari keuntungan semata, bukan kegiatan sosial.

Motif mendapatkan keuntungan sebesar-besarnya, yang dikembangkan oleh Adam Smith sebagai ekonom pertama di dunia (1723-1790), yang kemudian dikembangkan oleh berbagai ilmuwan seperti Thomas Malthus (17661834), selalu menjadi pegangan setiap pelaku usaha. Kemudian, secara eksternal

${ }^{15}$ Ibid, faktor penyebab atau alasan pelaku usaha melakukan perbuatan curang, diantaranya yaitu:

1. Ketentuan peraturan perundangundang yang belum memberikan perlindungan hukum secara maksimal terhadap pelaku bisnis yang dirugikan.

2. Lemahnya pemahaman penegak hukum berkaitan dengan kegiatan bisnis sehingga ada beberapa perbuatan yang telah memenuhi unsur tindak pidana tetapi tidak dapat dilakukan penegakkan hukumnya.

3. Persaingan usaha yang semakin ketat, memacu pelaku bisnis untuk menang dalam persaingan melalui cara-cara yang bersifat curang dalam mengejar kepentingan ekonominya. Persaingan adalah proses sosial yang melibatkan individu atau kelompok yang saling berlomba dan berbuat sesuatu untuk mencapai kemenangan tertentu.

4. Kondisi ekonomi. Dalam dunia bisnis, pasang surut keuntungan menjadi suatu hal yang yang sangat diperhatikan, karena jika suatu produksi tidak disambut baik oleh konsumen dengan daya beli masyarakat, maka produsen tidak mendapat keuntungan, dan bahkan dapat bangkrut.

Apabila faktor-faktor di atas, dijadikan pisau analisis dalam mengkaji penyebab pelaku usaha melakukan perbuatan curang dibidang agribisnis peternakan ayam, khususnya penyediaan sarana produksi ternak (pakan ayam, anak ayam, obat- 
obatan), maka didasarkan selain faktor intern juga didasarkan pada faktor ekteren. Salah satu faktor intern penyebab pelaku usaha melakukan kegiatan curang dalam bisnis pakan ayam, yaitu faktor moral dan etika dalam menjalankan bisnis, melakukan modus tidak dilakukannya pembayaran atas pakan yang telah disuplai dan hal itu dilakukan bukan hanya kepada satu pelaku usaha tetapi kepada pelaku usaha yang lainnya. Kemudian, faktor ekteren penyebab pelaku usaha melakukan perbuatan curang, yaitu peluang bisnis di bidang perternakan khususnya ternak ayam yang sangat potensial, karena pangsa pasar ayam di Indonesia sangat besar. Dapat dilihat dari berbagai macam hidangan lokal maupun luar yang menggunakan ayam. Banyaknya rumah makan/restoran yang menyajikan makanan dengan bahan baku ayam.

Sebagaimana telah dijelaskan di atas bahwa perbuatan curang dalam kegiatan bisnis adalah mencari keuntungan pribadi tanpa melihat aspek halal/haram, sehingga penguasaan barang yang menjadi objek jual-beli dilakukan secara melawan hukum karena dilakukan tanpa pembayaran, yang berdampak merugikan pihak lain baik secara materi maupun immaterial. Guna mencegah dampak negatif perbuatan curang dalam kegiatan bisnis maka perlu penegakkan hukum. Jika mengutip Teori Sistem hukum sebagaimana dikemukakan oleh Lawrence Meir Friedman menyebutkan ada 3 (tiga) inti pemikiran dalam Sistem hukum, yaitu:
a. Struktur Hukum (Legal Structure);
b. Substansi Hukum (Legal Substance);
c. Budaya Hukum (Legal Culture);

\section{Berdasarkan Kamus Besar Bahasa Indonesia lembaga berarti badan (organisasi) yang tujuannya melakukan suatu penyelidikan keilmuan atau melakukan suatu usaha. Lembaga juga berarti pola perilaku manusia yang mapan, terdiri atas interaksi sosial berstruktur dalam suatu kerangka nilai yang relevan, sedangkan penegak hukum diartikan sebagai petugas yang berhubungan dengan masalah peradilan. ${ }^{16}$ \\ Penyelesaian Perkara Terhadap Pelaku Tindak Pidana Curang dan Tantangannya.}

Merujuk pada proses dan mekanisme penyelesaian perkara pidana menurut KUHAP, maka penyelesaian perkara terhadap pelaku Tindak Pidana Curang daalam kegiatan bisnis dilakukan meliputi 3 (tiga) tahapan, sebagai berikut:

1. Tahap pemeriksaan di tingkat penyidikan;

2. Tahap penuntutan (Penyelesaian Perkara di Kejaksaan);

3. Tahap pemeriksaan di sidang pengadilan.

Para penegak hukum melaksanakan fungsi masing-masing sesuai dengan kewenangannya, dengan memastikan pasal yang disangkakan tersebut memenuhi unsur-unsur pidananya. Penerapan sanksi pidana terhadap pelaku yang melakukan perbuatan curang dalam bisnis, khususnya Pasal 379a KUHP.

1. Unsur-Unsur Objektif.

a. Perbuatan Membeli.

\footnotetext{
16 Diakses melalui http://www.hukumonline.com/klinik/detail/lt50220 1cc74649/siapa-sajakah-penegak-hukum-diindonesia, pada tanggal 13 Agustus 2015, pada Pukul 12.00 WIB.
} 
Jual beli, sesuai Pasal 1457 KUH Perdata adalah suatu persetujuan dimana pihak yang satu (disebut penjual) mengikatkan dirinya untuk menyerahkan suatu benda dan pihak yang lain (disebut pembeli) untuk membayar harga yang telah dijanjikan.

b. Objeknya.

Benda-benda atau barang.

1) Benda bergerak dan benda tetap;

2) Benda berlainan lebih dari satu.

c. Sebagai mata pencaharian (beroep) atau kebiasaan (gewoonte).

1) Mata pencaharian, dilakukan cukup hanya satu kali namun dari hal lain yang dilakukannya dapat disimpulkan akan dilakukannya kembali;

2) Kebiasaan, dilakukan lebih dari satu kali. ${ }^{17}$

2. Unsur-Unsur Subjektif.

Maksud untuk memastikan kekuasaan atas benda bagi dirinya sendiri maupun orang lain tanpa membayar lunas.

a. Maksud berupa unsur kesalahan;

b. Maksud ditujukan pada:

1) Memastikan menguasai benda baik bagi dirinya maupun orang lain.

a) Unsur menguasai sama dengan unsur

17 Fachrizal Afandi, Penipuan/Bedrog, Makalah, 2010, hlm. 16.

$$
\begin{aligned}
& \text { menguasai dalam } \\
& \text { penggelapan; } \\
& \text { b) } \text { Orang lain/pelaku } \\
& \text { pembantu yang } \\
& \text { mempermudah } \\
& \text { terjadinya jual beli. }
\end{aligned}
$$

2) Tanpa membayar lunas. ${ }^{18}$

Apabila konsep penegakan hukum di atas, dikaji penerapannya pada proses penyelesaian kasus dari tindak pidana penipuan yang dilakukan pelaku bisnis berkaitan dengan suplai pakan. Maka, meskipun perbuatan pelaku bisnis tersebut telah memenuhi unsur-unsur tindak pidana sebagaimana diatur dalam Pasal 379a KUHP, bahwa perbuatan itu dilakukan sebagai mata pencaharian atau kebiasaan, karena perbuatan itu dilakukan berulangulang bukan hanya kepada satu pelaku usaha tetapi kepada pelaku usaha lainnya, sehingga memiliki indikasi adanya maksud tidak membayar lunas. Namun demikian, lembaga penegak hukum tidak menindaklanjuti lebih jauh karena alasan perkara merupakan kasus perdata bukan pidana, sehingga tujuan penerapan ketentuan Pasal 379a KUHP terhadap pelaku usaha yang melakukan perbuatan curang tidak tercapai, dalam: 1. memberi kepastian hukum; 2 . memberikan kesebandingan hukum; dan 3. memberikan perlindungan hukum bagi para pihak yang terkait, belum dapat diharapkan.

\section{PENUTUP}

Aspek-aspek hukum dalam penerapan sanksi pidana terhadap pelaku usaha yang melakukan perbuatan curang dam bisnis menurut perspektif Pasal 379a KUHP, bahwa Bisnis merupakan salah satu

\footnotetext{
${ }^{18}$ Ibid., hlm. 17.
} 
aktivitas usaha yang utama dalam menunjang perkembangan ekonomi, yang memiliki tujuan yang sama yaitu mendapatkan keuntungan sebesarbesarnya. Guna mendapatkan keuntungan tersebut, korporasi akan melakukan segala macam cara yang lazimnya tidak memperhatikan moral atau etika, karena berpandangan (1) Bisnis merupakan kegiatan usaha yang di dalamnya penuh persaingan, dan semua perilaku dari pihakpihak yang bersaing tersebut ingin keluar sebagai pemenangnya; (2) Bisnis adalah asosial, dan (3) Bisnis yang dicapuradukan dengan moral akan merugi dan tersingkir dengan sendirinya. Namun demikian, dampak dari pandangan yang keliru dalam kegiatan bisnis tersebut, bukan hanya memberikan kerugian kepada para pihak dengan siapa pelaku usaha tersebut melakukan hubungan hukum seperti jual beli, tetapi dapat pula memiliki dampak yang luas sehingga mengganggu perekonomian nasional, seperti monopoli dan persaingan usaha tidak sehat.

Guna melindungi pengusaha dari perbuatan curang pelaku usaha lainnya instrumen hukum pidana mengaturnya melalui Pasal 379a KUHP, dengan pidana penjara paling lama 4 tahun terhadap siapapun yang menjadikan sebagai mata pencaharian atau kebiasaan untuk membeli benda-benda, dengan maksud supaya tanpa dengan pembayaran seluruhnya, memastikan kekuasaannya terhadap benda-benda itu, untuk diri sendiri maupun orang lain. Faktor-faktor penyebab pelaku bisnis melakukan perbuatan curang yaitu:

a. Secara intern, didasarkan karena :

1) Lemahnya Sumber Daya Manusia (SDM);
2) Sikap atau rasionalisasi untuk membenarkan tindakan fraud;

3) Kurangnya kesadaran moral utilitarian (moral yang berkaitan dengan memaksimumkan hal terbaik bagi orang sebanyak mungkin);

4) Menurunnya formalism etis (moral yang berfokus pada maksud yang berkaitan dengan perilaku dan hak tertentu;

5) Pandangan yang salah dalam menjalankan bisnis, dimana tujuan utama bisnis adalah mencari keuntungan semata, bukan kegiatan sosial.

b. Secara eksternal faktor penyebab atau alasan pelaku usaha melakukan perbuatan curang, diantaranya yaitu:

1) Ketentuan peraturan perundang-undang yang belum memberikan perlindungan hukum secara maksimal terhadap pelaku bisnis yang dirugikan;

2) Lemahnya pemahaman penegak hukum berkaitan dengan kegiatan bisnis;

3) Persaingan usaha yang semakin ketat, memacu pelaku bisnis untuk menang dalam persaingan melalui cara-cara yang bersifat curang dalam mengejar kepentingan ekonominya;

4) Kondisi ekonomi.

Penegakan hukum terhadap pelaku bisnis yang curang adalah proses dilakukannya upaya untuk tegaknya atau berfungsinya norma-norma hukum secara 
nyata sebagai pedoman perilaku dalam lalu lintas atau hubungan-hubungan hukum dalam kehidupan bermasyarakat dan bernegara. Penegakan hukum oleh lembaga penegak hukum didasarkan pada prinsip "Nullum Delictum Nulla Poena Sine Praevia Lege Poenali", sebagaimana tercantum pada Pasal 1 ayat (1) Wetboek Van Strafrecht atau lebih dikenal dengan KUHP (Kitab Undang-undang Hukum Pidana), yang artinya "Tidak ada suatu perbuatan dapat dipidana (dihukum) sebelum ada undang-undang yang mengatur perbuatan tersebut. Adapun proses dan mekanisme penyelesaian perkara pidana termasuk perbuatan curang dalam kegiatan bisnis menurut KUHAP, dilakukan melalui: 1. Tahap pemeriksaan di tingkat penyidikan; 2. Tahap penuntutan; dan 3. Tahap pemeriksaan di sidang pengadilan.

Namun, tidak selamanya proses penegakan hukum terhadap pelaku bisnis yang curang dapat diwujudkan melalui penerapan Pasal 379a KUHP, meskipun unsur-unsur tindak pidananya telah terpenuhi seperti perbuatan itu dilakukan sebagai mata pencaharian atau kebiasaan. Namun demikian, lembaga penegak hukum tidak menindaklanjuti lebih jauh, sehingga tujuan, sehingga tujuan hukum dalam memberikan kepastian hukum; memberikan kesebandingan hukum; dan memberikan perlindungan hukum bagi para pihak yang terkait, belum dapat diwujudkan. Sebaiknya aspek-aspek dalam Pasal 379a KUHP harus lebih diperhatikan untuk ditindak oleh aparat penegak hukum, agar sesuatu yang menjadi mata pencaharian tersebut termasuk kegiatan yang melawan hukum. Sebaiknya para pelaku usaha dalam melakukan kegiatan bisnis, dalam hal ini jual-beli, dilandasi dengan etika bisnis. Sebaiknya para penegak hukum dapat lebih jeli dalam menempatkan suatu kasus, apakah perdata/pidana, sehingga terhadap hubungan hukum yang bersifat perdata seperti jual beli, namun di dalamnya dapat dibuktikan adanya unsur-unsur tindak pidana, untuk melakukan penegakan hukum melalui instrument hukum pidana sebagaimana diatur dalam Pasal 379a KUHP.

\section{DAFTAR PUSTAKA}

\section{Buku.}

A.K. Mihardja, Polemik Kebudayaan, Jakarta: Balai Pustaka, 1998.

Abdi Anwar Rasyid, Ilmu Sosial Dasar; Manusia Sebagai Makhluk Sosial, Bandung: Bina Cipta, 2013.

Es. Mahmoedin, Etika Bisnis Perbankan, Jakarta: Pustaka Sinar Harapan, 1994.

Leden Marpaung, Asas, Teori dan Praktik

Hukum Pidana, Sinar Grafika, Bandung, 2006.

P.A.F. Lamintang, Dasar-Dasar Hukum

Pidana Indonesia, Bandung: Citra

Aditya Bakti, 1997.

\section{Peraturan Perundang-Undangan.}

Undang-Undang Dasar Negara Republik Indonesia Tahun 1945.

Undang-Undang Nomor 1 Tahun 1946 Tentang Kitab Undang-Undang Hukum Pidana.

Staatsblaad nomor 23 Tahun 1847 Tentang Burgerlijk Wetboek voor Indonesie.

Undang-Undang Nomor 7 Darurat 1955 Tentang Peraturan Pidana Khusus. 
Undang-Undang Nomor 8 Tahun 1981

Tentang Kitab Undang-Undang

Hukum Acara Pidana.

Undang-Undang Nomor 8 Tahun 1999

Tentang Perlindungan Konsumen.

Undang-Undang No. 5 Tahun 1999

Tentang Larangan Praktek Monopoli dan Persaingan Usaha Tidak Sehat.

\section{Makalah}

Bimo Adi Wicaksono, Pengaruh Iptek

Dalam Kehidupan Sehari-hari, artikel dalam

http://www.blogspot.com/2010_06_01

_archive.html, diakses tanggal 9

Desember 2014.

Herman Susetyo, Pelaku Kejahatan

Bisnis,

Dampak

dan
Tanggungjawabnya,

Makalah disampaikan Pada Bagian Keperdataan Pada Tanggal 9 Januari 1995, Fakultas Hukum Universitas Diponegoro, 1995 Indah Kusumawardani, Pengertian Bisnis Secara Umum Menurut Ahli, artikel dalam http: //www.apapengertianahli.com/2014/09 /pengertian-bisnis-menurut-paraahli.html, diakses tanggal 23 Februari 2015.

Muladi, Fungsionalisasi Hukum Pidana Di Dalam Kejahatan Yang Dilakukan Oleh Korporasi, Makalah, Fakultas Hukum UNDIP Semarang, 1989.

\section{Internet}

http: // www.hukumonline.com 